Information Management and Business Review

Vol. 2, No. 3, pp. 118-124, Mar 2011

\title{
E-Banking: Problems and Prospects an Empirical Study in Punjab
}

\author{
R. K. Uppal \\ Project Director UGC Sponsored MRP, D.A.V. College, Malout (Punjab) \\ rkuppal_mlt@yahoo.com
}

\begin{abstract}
The present study is concerned with the problems and prospects of e-banks in India. The present paper suggests some policies on the basis of perceptions of 60 selected e-bank employees regarding the various issues related to e-banking services. The paper concluded that not more then $50 \%$ of Indian bank customers are using e-channels, these channels are not much popular among old age and middle age persons as much as among youngsters and finally the paper concludes that the most of the customers are shifting from public sector banks to new private sector banks or foreign banks to avail innovative and attractive services. On the basis of these conclusions, paper suggests some strategies to make the public sector banks more competitive in the era of IT.
\end{abstract}

Keywords: E-Services in Banks, Users of E-Channels, Performance of E-Banks, Customer Preferences to EChannels, Reasons to Use E-Channels

\section{Introduction}

IT revolution has converted the world into a global village. The thinking, structure, work-culture and functioning styles are changing on hour basis. IT has created tremendous job opportunities for the people around the globe as well made the organizations efficient and productive. There has been an IT revolution in the world in the last 40 years. This revolution has altered the way we work and think. It has touched every enterprise, sector, society and government where banking is the most triggered area. IT has created tremendous job opportunities for the people around the globe, and has made the organizations efficient and productive. In most of the developed countries like USA, it has contributed to half of the productive growth and a third of the economic growth over the last five years. In India most of the organizations have already deployed IT to transform their processes. Government of India is even practicing e-governance and offering single window solutions to the customers. Recent developments in IT have introduced a plethora of opportunities for development in banking industry too. IT as an enabler has broken all bounds of cost, distance and time.

In the pre 1991 era, Indian banking system was suffering from number of internal and external factors, the financial and qualitative aspect was deteriorated but in the post-second banking sector reforms era gained momentum. IT Act of 1999 further accelerated the strength of the Indian Banking System. But unfortunately, the biggest sector in the Indian banking sector i.e. public sector banks have not gained as much as private sector. The gap is continuously increasing between the public sector banks and private sector banks and moreover, public sector banks are facing number of challenges regarding the use of e-delivery channels. Except some banks, others are unable to face the global challenges due to lack of use of advanced technology. The present paper investigates the perceptions of e-bank employees and based on these perceptions, some suggestions are made for the survival of public sector banks and will provide an opportunity to the academicians, IT consultants, research scholars, practitioners and students to go through for further detailed studies in this area. Modern technology has transformed the functioning of business. It has bridged the gaps in terms of the reach and the coverage of systems and enabled better decision-making based on latest and accurate information, reduced cost and overall improvement in efficiency. In the Indian context, the financial sector, especially the banking sector has been a major beneficiary from the inroads made by IT. Many new processes, products and services offered by banks and other financial intermediaries are now IT centered. Now-a-days many banks are providing the services through e-channels like ATMs, I-banking, M-banking, Tele-banking, Debit cards, Credit cards etc. Most of the initiatives regarding e-channels are aimed at providing better and more efficient customer service by offering multiple options to the customers. 
With the rapid improvements in technology and faster growth of e-channels, society has become more sophisticated than in olden days. We have a better educated, better informed, better organized and better paid workforce than existed in olden days. With the help of e-channels, banking system has become more efficient with efficient e-payment system. The main challenge ahead in the new millennium in banking and financial sector contain changing economic and banking environment, global competition, capital structure, transparency in reporting accounts, employee productivity, risk management, market discipline, sound human resource management, training and development. The best approach to customer retention is to deliver high level of customer satisfaction that result in, strong customer loyalty. Two-stage factor analysis was computed to arrive at the dimensions of customer satisfaction. The study analyzed ten factors and five dimensions of customer satisfaction for nationalized and private sector banks respectively. This situation has resulted in more competition among banks and stimulated more technological developments. Customers are getting many benefits from e-services like balance enquiry, request for services, issuing instruction etc from anywhere in the world are possible, any time banking, convenience acts as a tremendous psychological benefit all the time, cash/card free banking through PC banking, brings down "cost of banking" to the customer over a period of time, cash withdraw from any branch, on-line purchase of goods and services including on-line payment for the same. With so many benefits from e-services, it is a need of an hour to study the satisfaction level of customers from these e-services. This paper studies the satisfaction of the customers from different e-services with the objective to know the perceptions of employees regarding the available ebanking services. To suggests the policies/strategies to create awareness about e-channels. The present paper is divided into six parts. After the brief introduction of the theme, the second part is devoted to review of literature. The third part describes the objective and methodology for the study. Fourth part exhibits the results. Fifth part suggests some measures for the survival of public sector banks in the changed scenario. Last part concludes the paper with some future areas of comprehensive research.

\section{Review of Literature}

Hasanbanu (2004) studied customer services in rural banks. He found that the rural customers are not aware for what purpose the loans are available and how they can avail. Customers do not know the complete rules, regulations and procedures of the banks as they preserve them for themselves and do not take interest in educating them. Husain (1988) also highlighted the importance of IT in various sectors. In the introduction of any new technology or system, various organizational, financial \& functional problems are faced in the initial stages. People are generally reluctant to accept new system, howsoever beneficial it may be. Such various issues, which are involved in computerization, have been critically \& vividly discussed. Heggade (2000) studied bank customer relationship in India. He analyzed responses of 11 different classes of bank customers like businessmen, salaried, advocates, peasants etc. He analyzed customer's views on the one hand and employees view on the other hand. The paper concludes that there is a low correlation among the different occupations and satisfaction from services in the PSBs.

Banking world is undergoing a rapid and radical transformation due to impact of IT and incredible developments in telecommunication technology and electronic data processing (Pathrose, 2001). The winds of change are blowing in India as well. The integration of information system with communication technology has radically altered the traditional ways of banking business and allowed banks to wipe out the difference in time as well as distance. This article attempts to trace the present status of hi-tech banking in India, visualize its prospects and look at the challenges and problems in the tracks to be traversed. Study concludes that in the scenario of severe competition and escalating expectation of customers for newer products and alternative delivery channels, the contours of banking are being redefined. The key to survival of banks therefore is retention of customer's loyalty by providing them with value added services tailored to their needs, using state-of- the-art IT. There is no way a bank can remain lukewarm to hi-tech and yet hope to grow. It is a choice between survival and extinction. Sharma \& Singh (1993) analyzed the quality of customer services produced by Standard Charted Bank (SCB) and Punjab National Bank (PNB) (one branch of each bank situated in Hall Bazaar, Amritsar) with the sample of 40 respondents in total. They concluded that the quality of customer services of PNB branch is very poor in comparison to that of SCB branch. But the main limitation of the study is that it is related to two banks only. Singh \& Malhotra (1993) analyzed customer satisfaction in banking services in the Amritsar city. They concluded that public sector banks should improve their services to attract the new customers. Bank management should prepare the list of existing and 
prospective customers and carry out detailed studies on customer satisfaction in order to improve their services. But this study is limited to only one district of Punjab.

Singh (2004) explained the appraisal of customer service of PSBs and concluded that level of customer services and satisfaction is determined by the branch location, design, variety of services, rates and changes, systems and procedures and attitude and responses. His study is purely concerned with the customers of PSBs. Sharma \& Kaur (2004) studied strategies of customer satisfaction in rural banks. This study is concerned with Hoshiarpur district of Punjab. They used five-point likert scale and found that the rural customers are not satisfied from the strategies adopted by Gramin Bank. Shastri (2001) analyzed the effect and challenges of new technology for banks. Technology has brought a sea change in the functioning of the banks. The earlier manual system of preparation of vouchers, etc. is slowly being automated thereby saving a lot of time \& effort. The use of ATMs and introduction of IT more than in the past especially in the Post- VRS Scenario. Shanti (1984) has made a pioneering attempt to examine the issues relating delivery of customer services in Indian banks as against the backdrop of a sound conceptual framework. She has provided as empirical analysis of bank employee's job behavior and its relationship with bank services delivery. She has found that lack of job motivation, lack of freedom at branch level, lack of leadership qualities among bank managers, job security etc. have resulted in poor quality customer services in Indian banks.

Uppal (2006) with stratified sampling of 500 bank customers, explained the impact of computerization on the satisfaction of customers of all bank groups and concluded that customer services are quite better in fully computerized banks and further in e-banks as compared to that in partial or non-computerized banks. The study was concerned only with the urban sector of Punjab. But the study is only concerned with the urban sector of Punjab. Varghese \& Ganesh (2003) analyzed customer services in PSBs and old private sector banks based on the responses of 776 customers of 10 PSBs and 13 old private sector banks operating in Kerala. They found regarding 'time' spent on a transaction where there is no difference in the two types of the bank branches. Verma (2000) analyzed the impact of IT on PSBs \& NPSBs in her article 'Banking on Change'. The IT is a threat for the PSBs. It has to be a complete face off for the PSBs. With the business per employee, even for the front-run PSBs, a mere fraction of that of NPSBs, the PSBs have to do a lot on improving their productivity \& efficiency. NPSBs are fully computerized \& providing services on Internet. Especially ICICI bank, HDFC bank is very active on this front $\&$ is concentrating on Internet \& e-commerce to offer their clientele a whole range of products under one roof. New banks like GTB, BOP, and IDBI \& UTI bank are not lagging behind. While some of them are concentrating on expansion \& modernization, some are focusing on mergers and acquisitions for their growth.

\section{Methodology}

The methodology adopted for this study was based on primary data collected through well-defined and wellstructured questionnaires. The study is based on a sample of 60 employees working with e-channels and having experience in dealing with customers through e-channels. The survey was conducted in the month of January 2007 in different cities of Punjab as Ludhiana, Bathinda, Jalandhar, Patiala and Sangrur. A sample size of 60 bank employees has been taken due to shortage of time. The employees of only e-banks having experience in dealing with e-channels were surveyed for the study. Data was analyzed with the help of percentage method; ranking and weighted average score (WAS) methods. The respondents were asked to respond on a five-point likerts scale i.e. strongly agree, agree, undecided, disagree, strongly disagree regarding various statements. Weights of $2,1,0,-1,-2$ were assigned to these levels of scale respectively for calculating the weighted average score. On the other hand for the purpose of ranking, the following step-bystep methodology has been followed:

First Step: Firstly, in respect of some comparative issues, the number of times a factor occupied the $1^{\text {st }}, 2^{\text {nd }}, \ldots$. Nth ranks were computed in terms of frequency.

Second Step: Weights were assigned to each rank in the descending order. For example in collaborative culture aspect, there are three factors with three ranks, weightage pattern was as follows: $1^{\text {st }}$ rank $-3,2^{\text {nd }}$ rank $-2 \& 3^{\text {rd }}$ rank -1 .

Third Step: The sum of the above given weights, for all the ranks, were calculated which is denoted in the tables as total score. 
Fourth Step: Overall ranks were assigned on the basis of total score values for each factor calculated in the above step.

\section{Findings of the Study}

\section{Socio-Economic Background of the Respondents}

The socio-economic background of the employees affects their perceptions deeply about every aspect. The results in table- 1 (a) \& (b) reveals that out of 60 respondents, 32 pc are under the age of 26 years, 27 pc are between the age of 26 to 35 years where others are above the age of 36 years. 82 pc are males and 58 pc are having master degree as well qualified. 42 pc are working in banks for less than 3 years where 40 pc are working with the banks for more than 7 years. On the other hand, majority of the respondents i.e. $55 \mathrm{pc}$ are at manager scale and only $17 \mathrm{pc}$ are clerks.

Table 1 (a): Socio-Economic Background of the Respondents

\begin{tabular}{|c|c|c|c|c|c|c|c|c|}
\hline & Age & & & iual Income & & Educatic & ial Qualifica & \\
\hline Range & Responses & \%age & $\begin{array}{l}\text { Range } \\
\text { (Lacs) }\end{array}$ & Responses & \%age & Range & Responses & \%age \\
\hline $\begin{array}{l}\text { Less than } \\
26\end{array}$ & 19 & 32 & $\begin{array}{l}\text { Less than } \\
1\end{array}$ & 8 & 13 & High School & 3 & 5 \\
\hline 26 to 35 & 16 & 27 & 1 to 2 & 25 & 42 & $\begin{array}{l}\text { Bachelor } \\
\text { Degree }\end{array}$ & 22 & 37 \\
\hline 36 to 45 & 11 & 18 & 2 and & 27 & 45 & $\begin{array}{l}\text { Master } \\
\text { Degree }\end{array}$ & 35 & 58 \\
\hline Above 45 & 14 & 23 & above 2 & 21 & 45 & $\begin{array}{l}\text { Doctorate } \\
\text { Degree }\end{array}$ & 0 & 0 \\
\hline
\end{tabular}

Source: Computed from Data Collected through Survey

Table 1 (b): Socio-Economic Background of the Respondents

\begin{tabular}{lcclcc}
\hline Range (Years) & $\begin{array}{c}\text { Job Duration } \\
\text { Responses }\end{array}$ & Percentage & \multicolumn{1}{c}{ Category } & $\begin{array}{c}\text { Category of Job } \\
\text { Responses }\end{array}$ & Percentage \\
\hline Less than 3 & 25 & 42 & Manager & 33 & 55 \\
3 to 4 & 6 & 10 & Executives & 17 & 28 \\
5 to 6 & 5 & 3 & Clerks & 10 & 17 \\
Above 6 & 24 & 40 & & & \\
\hline
\end{tabular}

\section{Main findings regarding the perceptions of the employees}

Table- 2 reveals that $55 \mathrm{pc}$ of the respondents opines that overall performance of the e-channel using banks has been improved to large extent and $32 \mathrm{pc}$ said that it is improved to some extent but only $2 \mathrm{pc}$ are against the statement. Overall, the performance of the banks has been improved due to the use of e-channels.

Table 2: Responses Regarding the Overall Performance of E-banks

\begin{tabular}{ccccc}
\hline To Large Extent & To Some Extent & A Little & Very Little & Not At All \\
\hline 33 & 19 & 6 & 1 & 1 \\
$(55.00)$ & $(31.67)$ & $(10.00)$ & $(1.67)$ & $(1.67)$ \\
\hline
\end{tabular}

Table- 3 shows that $58 \mathrm{pc}$ of the respondents observed that less than 70 pc customers are using e-channels in India. Only 27 pc opines that 70 to 80 pc customers are using e-channels. Hence, it can be concluded that not more that $70 \mathrm{pc}$ of customers in India are using these e-channels mainly due to high rate of illiteracy and lack of knowledge. 
Table 3: Responses Regarding the Use of E-channels by the Customers for Availing Bank Services

\begin{tabular}{ccc}
\hline Percentage Range & Number of Responses & Percentage \\
\hline $100-90$ & 5 & 8.33 \\
$91-80$ & 4 & 6.67 \\
$81-70$ & 16 & 26.67 \\
Less than 70 & 35 & 58.33 \\
\hline
\end{tabular}

From Table 4, it is observed that $47 \mathrm{pc}$ of the respondents (employees) experiencing increase in the number of customers using e-channels to some extent but 28 pc observed this increase to large extent. The main reason for slow growth of number of customers to use e-channels is the lack of their faith as frauds are increasing day by day and insecurity to loose confidential information.

Table 4: Responses about Increase in Number of Customers Accessing E-channels

\begin{tabular}{ccccc}
\hline To large extent & To some extent & A Little & Very Little & Not at all \\
\hline 17 & 28 & 13 & 2 & 0 \\
$(28.33)$ & $(46.67)$ & $(21.67)$ & $(3.33)$ & 0 \\
\hline
\end{tabular}

Table 5 reveals that $70 \mathrm{pc}$ of the respondents opines that most of the users of e-channels fall in the age group of 26 to 35 years while $22 \mathrm{pc}$ are in favour of the users of age group of 15 to 25 years. Hence, it is observed that most of the users are of young age where these channels are still not much popular among the old age persons.

Table 5: Responses Regarding Preference of E-channels Among Different Age Groups

\begin{tabular}{ccc} 
Age-Groups & Number of Responses & Percentage \\
\hline 15 to 25 years & 13 & 21.67 \\
26 to 35 years & 42 & 70.00 \\
36 to 45 years & 4 & 6.67 \\
Above 45 years & 1 & 1.67 \\
\hline
\end{tabular}

Table 6 shows that $41 \mathrm{pc}$ of the respondents are strongly agree with the statement that there is a very fast shifting of bank customers from traditional banks to e-banks and it has strong importance as its WAS is more than 1 i.e. 1.23. Therefore, it can be said that shifting of bank customers is an alarming factor for the public sector banks to start e-services to maintain their market share.

Table 6: Responses Regarding Shifting of Bank Customers from Traditional to E-banks

\begin{tabular}{cccccc}
\hline Strongly Agree & Agree & Undecided & Disagree & Strongly Disagree & WAS \\
\hline 17 & 41 & 0 & 2 & 0 & 1.23 \\
\hline
\end{tabular}

Table 7 exhibits that according to 23 pc of the respondents, rate of people accepting e-channels in India is 41 to $50 \mathrm{pc}$ whereas $18 \mathrm{pc}$ are in favour of rate between 11 to $20 \mathrm{pc}$ but only $10 \mathrm{pc}$ said the rate is above $60 \mathrm{pc}$. Hence, we may conclude that still not $50 \mathrm{pc}$ of the people in India has accepted e-channels for dealing with banks.

Table 7: Responses Regarding Acceptance of E-channels in India (approx.)

\begin{tabular}{ccc}
\hline Range & Number of Responses & Percentage \\
\hline $0-10$ & 6 & 10.00 \\
$11-20$ & 11 & 18.33 \\
$21-30$ & 6 & 10.00 \\
$31-40$ & 7 & 11.67 \\
$41-50$ & 14 & 23.33 \\
$51-60$ & 10 & 16.67 \\
Above 60 & 6 & 10.00 \\
\hline
\end{tabular}


From table 8 it is observed that majority of the respondents awarded the strategy of provide customer services according to their requirements with first rank so is the most important and effective whereas the strategies such as award the customers with the longest relations with the bank, make competitive strategies are in succession.

Table 8: Responses for Suggestions to Retain Old and Attract New Customers

\begin{tabular}{|c|c|c|c|c|c|c|c|c|c|}
\hline Factors & R-1 & $\mathbf{R}-2$ & $\mathbf{R}-\mathbf{3}$ & $\mathbf{R}-4$ & R-5 & R-6 & $\mathbf{R}-7$ & $\begin{array}{l}\text { Total } \\
\text { Score }\end{array}$ & $\begin{array}{c}\text { Overall } \\
\text { Rank }\end{array}$ \\
\hline $\begin{array}{l}\text { (i) Customers with longest bank } \\
\text { relations should be awarded }\end{array}$ & 17 & 7 & 6 & 13 & 10 & 3 & 4 & 283 & 2 \\
\hline (ii) Distribute free gifts & 3 & 5 & 7 & 2 & 5 & 13 & 25 & 160 & 7 \\
\hline (iii) Make competitive strategies & 10 & 15 & 5 & 3 & 8 & 11 & 8 & 251 & 3.5 \\
\hline $\begin{array}{l}\text { (iv) Offer shares of the bank at lesser } \\
\text { cost to old customers }\end{array}$ & 5 & 6 & 6 & 5 & 9 & 18 & 11 & 195 & 6 \\
\hline $\begin{array}{l}\text { (v) Provide loans at slightly lesser } \\
\text { rate as compared to going on } \\
\text { rates of interest }\end{array}$ & 4 & 8 & 11 & 15 & 12 & 5 & 5 & 242 & 5 \\
\hline $\begin{array}{l}\text { (vi) Provide services according to } \\
\text { their requirements }\end{array}$ & 15 & 15 & 9 & 10 & 5 & 4 & 2 & 305 & 1 \\
\hline $\begin{array}{l}\text { (vii) Their suggestions should be } \\
\text { considered }\end{array}$ & 7 & 5 & 15 & 12 & 11 & 6 & 4 & 251 & 3.5 \\
\hline
\end{tabular}

Table 9 analyzes some strategies to motivate the customers to use more e-channels. All the strategies such as eliminate fear of insecurity, introduce more ATMs at convenient locations, make the customers aware about use of e-channels etc are observed as significant as their WAS is above 1.

Table 9: Responses for Strategies to Motivate the Customers to Use More E-channels

\begin{tabular}{lcccccc}
\hline \multicolumn{1}{c}{ Statements } & SA & A & UD & D & SDA & WAS \\
\hline (i) More advertisements & 26 & 31 & 1 & 2 & 0 & 1.35 \\
(ii) More knowledge to customers regarding their use and & 33 & 21 & 6 & 0 & 0 & 1.45 \\
$\quad$ how to operate & 30 & 21 & 5 & 4 & 0 & 1.28 \\
(iii) Eliminate the fear of insecurity & 16 & 29 & 11 & 4 & 0 & 0.95 \\
(iv) Eliminate the frauds & 24 & 29 & 6 & 1 & 0 & 1.27 \\
(v) Make the cost of services affordable & 22 & 31 & 4 & 2 & 1 & 1.18 \\
(vi) Launch attractive schemes & 25 & 29 & 5 & 1 & 0 & 1.30 \\
(vii) Easy availability with lesser formalities of e-channels & 25 & 30 & 4 & 1 & 0 & 1.31 \\
(viii) Provide e-channel services according to customer needs & 22 & 30 & 8 & 0 & 0 & 1.23 \\
(ix) Remove technical deficiencies & 32 & 23 & 5 & 0 & 0 & 1.45 \\
(x) Introduce more ATMs at convenient locations & & & & & \\
\hline
\end{tabular}

\section{Suggestions for the Survival of Public Sector Banks}

a. Awareness should be created at a large scale particularly in the rural and semi-urban sector.

b. Trust should be created among the customers for all types of e-channels.

c. Workshops, training camps should be organized especially in rural and semi-urban areas.

d. Cost-free and cost effective e-channels should be made available for the priority sector.

e. Special incentives should be given to the customers with the longer relations, having accounts with large amount etc.

f. Feedback programme should be started to evaluate the performance so that timely actions can be taken in case of any discrepancy.

g. Special schemes to install/establish IT infrastructure in each and every branch of public sector banks.

h. Organize training to aware and train the employees of public sector banks to make them familiar with the e-channels relate all the aspects. 


\section{Conclusion}

After investigating the perceptions of e-banking employees, we may concludes that e-channels are preferred among the majority of the employees and the survival of the public sector banks depends upon the adoption of e-banking among all the segments of the society. The major problem is to change mind set of the old employees so that they can also adopt technology to cope up with the changing environment of globalization. With the use of latest technology along with productive human resources, the banks should come ahead to compete with their counterparts especially with competitive strategies. E-banking, if on one side a challenge for public sector banks, it provides bundle of opportunities on the other side which help them to gain more momentum and make them competitive in the changing environment. Therefore, public sector banks should adopt the technology as necessity not as an option as IT has no other alternative.

\section{Future Areas of Intensive Research}

1. A comprehensive study to find out crucial factors responsible for poor efficiency of public sector banks especially in e-banking era.

2. To suggest practical measures to make the public sector banks tech-savi from all aspects.

3. Detailed study of employees' perceptions to find reasons for not adopting e-banking and suggesting the motivating factors that can be helpful to accept e-banking for public sector banks.

\section{References}

Hasanbanu, S. (2004): Customer Service in Rural Banks: An Analytical Study of Attitude of different types of Customers towards banking services, IBA Bulletin, 26 (8): 21-29.

Husain, F. (1988): Computerization and Mechanization in Indian Banks, (New Delhi: Deep \& Deep Publication).

Heggade, O. D. (2000): Banker - Customer Relationship in India, (New Delhi: Mohit Publication).

Pathrose, P. P. (2001): Hi- Tech. Banking- Prospects and Problem, IBA Bulletin, 23 (7): 32-41.

Singh, S. (2004): An Appraisal of Customer Service of Public Sector Banks, IBA Bulletin, 26 (8): 30-37.

Sharma, R. D. \& Kaur, G. (2004): Strategy for Customer Satisfaction in Rural Banks - A case Study of Shivalik kshetriya Gramin Bank, Hoshiarpur, Prajnan, 33(1): 23-45.

Sharma, S. C. and Singh, J. (1993): Quality of Customer Service in Banks: A Comparative Study of SCB AND PNB, ed. (Radha Publication: New Delhi).

Singh, R. \& Malhotra, A. (1993): Customer Satisfaction in Banking Services: A Study of Amritsar, ed. (Radha Publication: New Delhi).

Shastri, R. V. (2001): Technology for Banks in India- Challenges, IBA Bulletin, 23 (3): 23-45.

Shanti, S. (1984) Customer Services in Banks, Himalaya Publishing House, Mumbai.

Uppal, R. K. (2006): Indian Banking and Information Technology, (New Delhi: New Century Publications).

Varghese, M. E. \& Ganesh, C. (2003): Customer Service in Banks: An Empirical Study, Vinimaya, 34(2): 15-26.

Verma, D. (2000): Banking on Change, ICFAI Reader (May): 69. 